
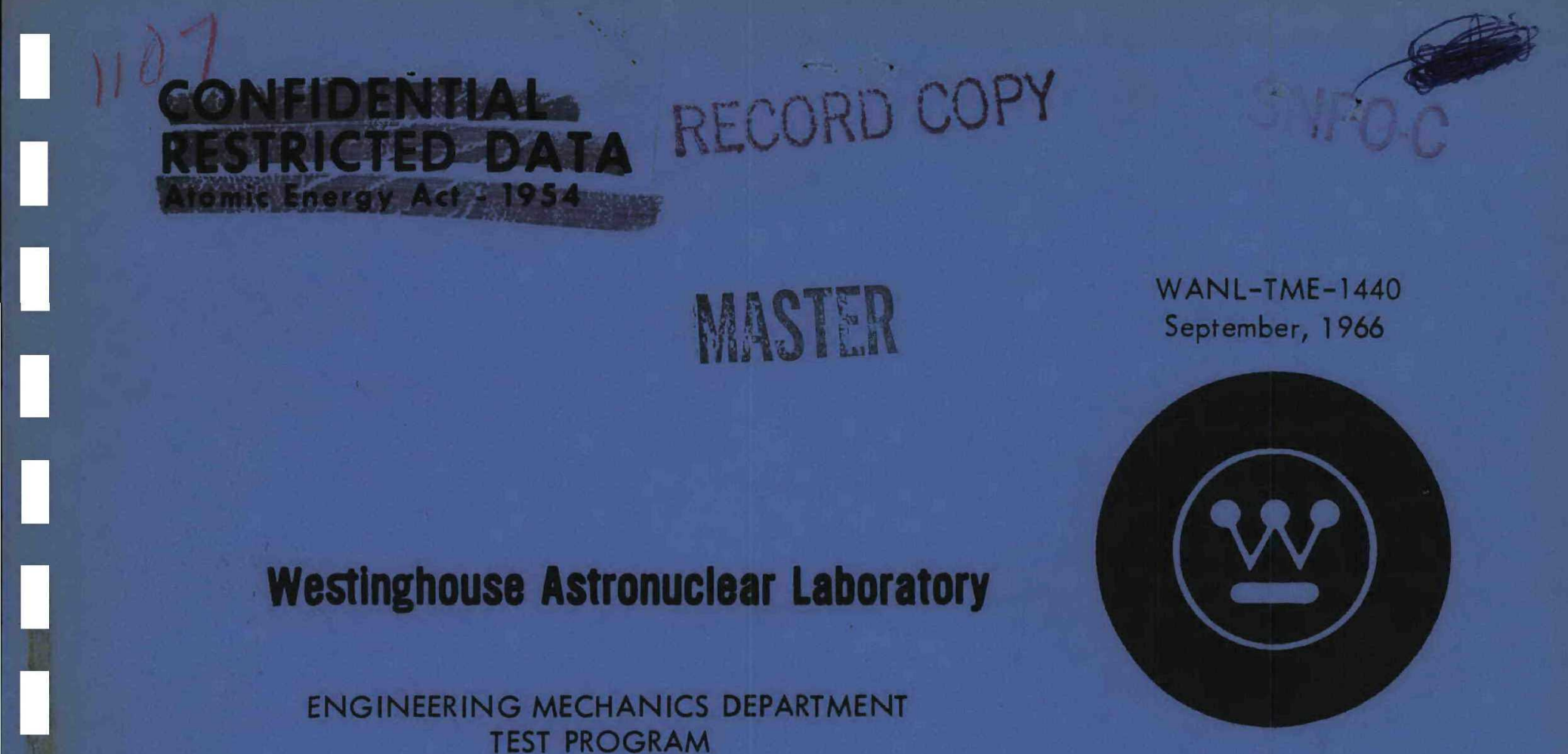
TEST PROGRAM

(Title Unclassified) 


\section{DISCLAIMER}

This report was prepared as an account of work sponsored by an agency of the United States Government. Neither the United States Government nor any agency Thereof, nor any of their employees, makes any warranty, express or implied, or assumes any legal liability or responsibility for the accuracy, completeness, or usefulness of any information, apparatus, product, or process disclosed, or represents that its use would not infringe privately owned rights. Reference herein to any specific commercial product, process, or service by trade name, trademark, manufacturer, or otherwise does not necessarily constitute or imply its endorsement, recommendation, or favoring by the United States Government or any agency thereof. The views and opinions of authors expressed herein do not necessarily state or reflect those of the United States Government or any agency thereof. 


\section{DISCLAIMER}

Portions of this document may be illegible in electronic image products. Images are produced from the best available original document. 


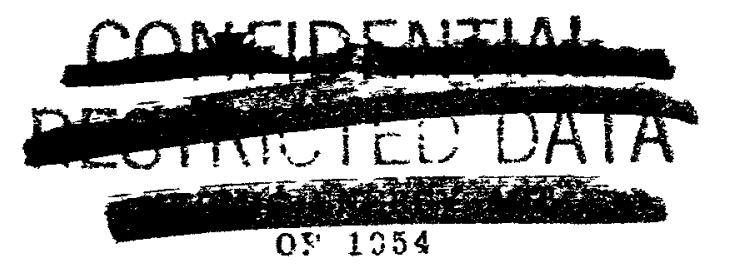

MASTER

Mr. J. L. Cooling

PERVA Subcontract Maniger

Rocket Engine Cperations - Nuclear

OCT -41966

Ceportment 71 w0

Aerolet-General Corporation

Post Cffice Box 15847

Secromenio, California 95813

Subject: BANL-TME-1440, "Engineering Mochonics Ceportment Test Progrom", (Title Unclassified) doted September, 1966

Dear Ar. Dooling:

Enclosed are ten (10) copies of WANL-TME-1440, "Engineering Machanics Depariment Tes: Program". This document describes the types of tests ws will be conducting on the rector components and sub-cssemblies in support of the NPX, XE and NR progroms. The moterial in this document is a result of a coordinated ffort between the Reactor Engineering ond Enginearing Mechanics Deportments.

Enclosures - 10

Respect fully,

H. F. FADGHT/RLS

H. F. Fought

Progrom Monezor

UN: J

cc: R. A. Schroeder, SNPC C, w/3 enclosures

SNPO-C Resident Office at "AML, $W / 1$ enclosure

G. Kalvin, SNiPO-C, wh anclosure

M. Gogne, $5 N$ PC $-C, w / 1$ enclosure

H. Murphy, SNPO $C, w / 1$ enclosure

R. ilke, SNPC-C, $w / 1$ enclosure

E. Liurys, SNPO-C, $w / 1$ enclosure

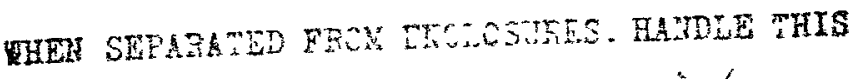

1. Helms, SNPO- $v, w / 1$ enclosure

i. Slivko, SNPO $:$ w $/$ enclosure

AGC Resident Cffice at :ANL $w / 0$ enclosure

"ANL Resident Cffice ot AGC, $w / 0$ enclosurs

U. Lecbetter, $A G C$ w $/$ enclosure

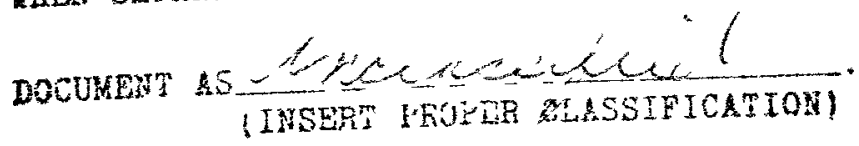




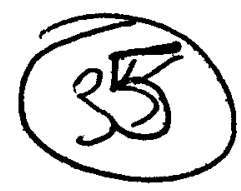

\title{
ENGINEERING MECHANICS DEPARTMENT TEST PROGRAM
}

(Title Unclassified)

\author{
Submitted By:
}

ENGINEERING MECHANICS DEPARTMENT

Westinghouse Electric Corporation

Astronuclear Laboratory

P. O. Box 10864

Pittsburgh, Pennsylvania 15236

This report was prepared as an account of work sponsored by the United States Government. Neither the United States nor the United States Energy Research and Development Administration, nor any of their employees, nor any of their contractors, subcontractors, or their employees, makes any warranty, express or implied, or assumes any legal liability or responsibility for the accuracy, completeness or usefulness of any information, apparatus, product or process disclosed, or represents that its use would not infringe privately owned rights.

\section{APPROVED BY:}

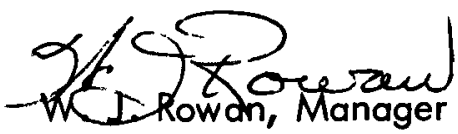

Engineering Mechanics

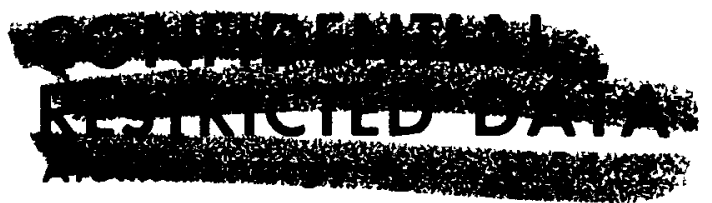

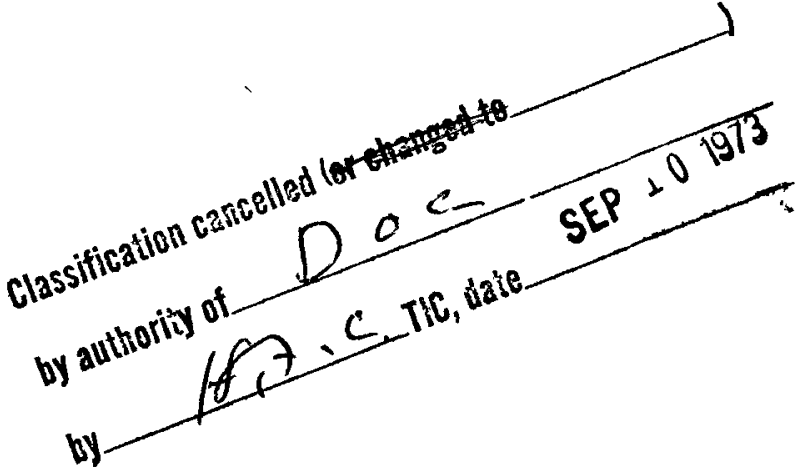
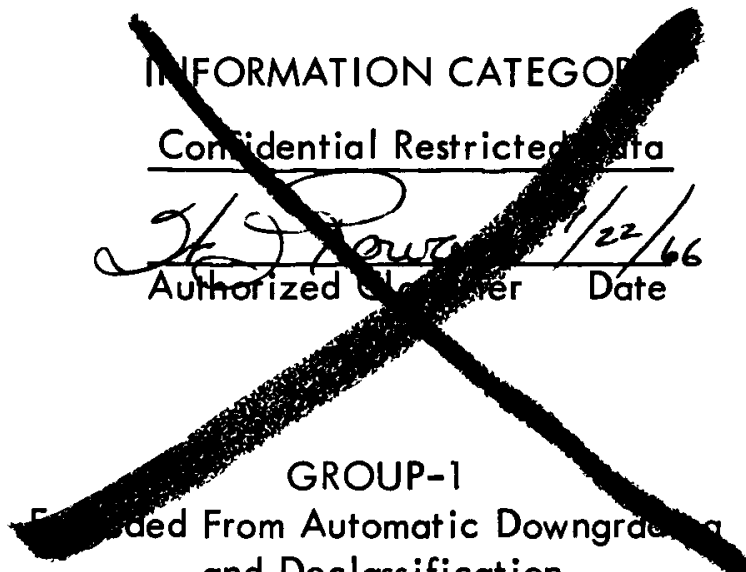

and Declassification

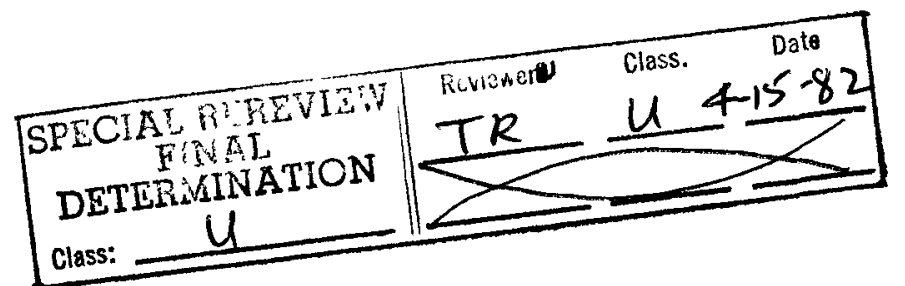

DISTRIBUTION OF THIS DOCUMENT UNLIMITEO 


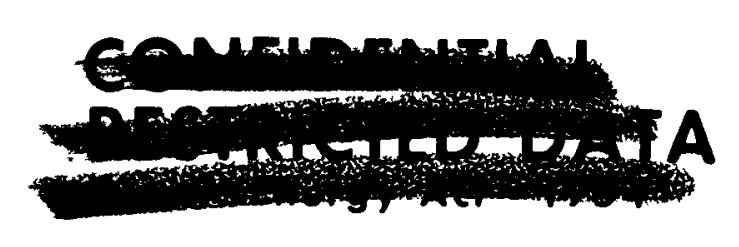

(2) Astronuclear

WANL-TME-1 440

\section{INTRODUCTION}

This document describes the program being conducted by the Engineering Mechanics Laboratory at WANL for the NERVA Program. It includes the work presently being performed and that which is planned for future reactor systems. The requirements for $C Y 1967$ and $C Y$ 1968 are primarily described, however, without extending the scope beyond this period the logic behind th is program would not be complete.

The work has been divided into three main areas: (1) the efforts devoted to the support of the NRX and XE reactor, (2) the general development program which includes tests pertinent to NERVA but not associated with a specific reactor, and (3) the tests which will be conducted to support the NR-1 reactor development. The program has also been subdivided into eight categories representing sections of the reactor or subjects which will be investigated for the three main area divisions.

Figure 1 is a summary table which relates the three main areas and eight categories. It also lists the specific tests which are contemplated in each category and the reason for the tests. When applicable, reference is made to other WANL documents that describe the NRX-A6 and NR-1 requirements.

The table of contents lists the categories, the proposed tests and the EML number designation which has been used with these tests to provide a continuity with our past work.

The body of the document includes a statement covering each category and a paragraph on each proposed test as defined in the summary table.

Detail scheduling of the various tests is not included in the document since it will fluctuate with the reactor design and delivery scheduling. The annual work statement, milestones, and the minutes of the monthly SNPO Review Meetings will provide continual up-dating of the scheduling for these tests.

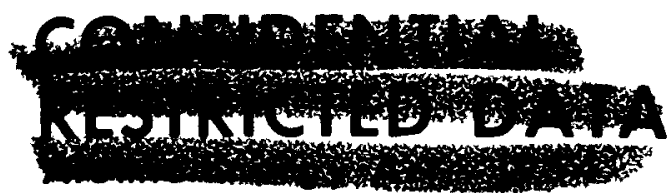




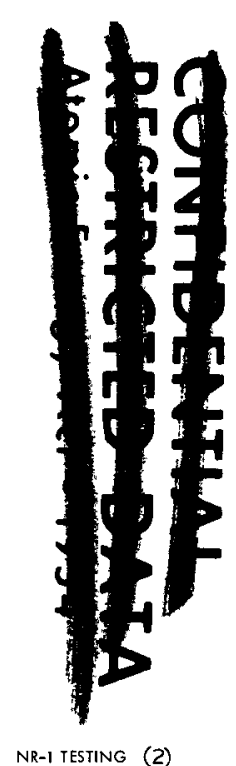

\begin{tabular}{|c|c|c|c|c|c|}
\hline \multirow[t]{6}{*}{ A. REFLECTOR SYSTEM TESTS } & $\begin{array}{l}\text { 1. OUTER REFLECTOR THEPMAL DISTORTION } \\
\text { TESTS (EML-82) }\end{array}$ & 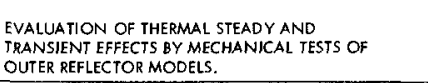 & & & $\longrightarrow A z-$ \\
\hline & 2. BERYLIUM PROPERTIES (EML-82) & $\begin{array}{l}\text { PROVIDE ELASTIC AND PLASTIK STRAAN PROPER- } \\
\text { TIES OF REFLECTOR MATERAL. }\end{array}$ & $-x-$ & & $-\mathrm{A} 5-$ \\
\hline & 3. REFLECTOR SEAL TESTS (EML-78) & $\begin{array}{l}\text { DETERMINE LEAK RATES UNDER REACTOR } \\
\text { CONDITIONS. }\end{array}$ & $-3.1,7.1-$ & & $-A_{1}-$ \\
\hline & 4. GANGED DRUM DRIVE TEST & $\begin{array}{l}\text { EVAUATER DESISNS UNDER ENVIRONMENTAL \& } \\
\text { CYCLING OPERATION. }\end{array}$ & & & $-B 1=$ \\
\hline & 5. CONTROL DRUM (OR SLEEVE) TESTS (EML-88) & $\begin{array}{l}\text { EVALAATE THE EEFECT OF THERMAL DISTORTION } \\
\text { IN CONTROL SLEEVE. }\end{array}$ & & & $-B 2,83-$ \\
\hline & 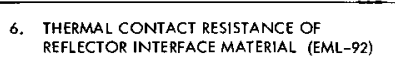 & 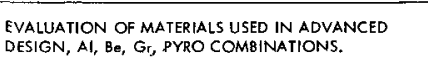 & & & $-\mathrm{C}_{4}-$ \\
\hline \multirow[t]{3}{*}{ B. FUEL ELEMENT TESTS } & $\begin{array}{l}\text { 1. FUEL ELEMENT STRENGTH AT TEMPERATURE } \\
\text { (EML-66) }\end{array}$ & 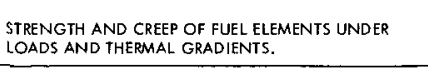 & $-\times-$ & & $-\mathrm{Fl} \longrightarrow$ \\
\hline & 2. FUEL ELEMENT COATING TEST (EML-67) & $\begin{array}{l}\text { DETERMINE INTEGRIY OF COATING AT } \\
\text { REACTOR TEMERAAURES. }\end{array}$ & & & $=F_{1}-$ \\
\hline & $\begin{array}{l}\text { 3. FUEL ELEMENT INSTRUMENTATION } \\
\text { INSTALLATION (EML-6G) }\end{array}$ & $\begin{array}{l}\text { EVALUATE EFFECTS OF THERMOCOUPLE } \\
\text { INSTALALTION IN VUEL ELEMENT. }\end{array}$ & & & 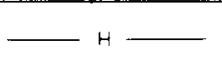 \\
\hline \multirow[t]{5}{*}{ C. AXIAL SUPPORT SYSTTEM TESTS } & $\begin{array}{l}\text { 1. SUPPORR BLOCK STRENGTH AT IEMPERATURE } \\
\text { (EML- } 9 \text { ) }\end{array}$ & 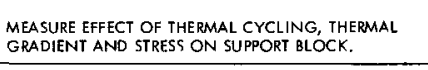 & $-6.2-$ & $\longrightarrow x-$ & $--G_{1}--$ \\
\hline & 2. CLUSTER DEVELOPMENT TESTING (EML-70) & $\begin{array}{l}\text { NEW CLUSTER DESIGN EVALUATION, LOAD, } \\
\text { GRADIENT, ETC. }\end{array}$ & & $-x-$ & $-62,63-$ \\
\hline & 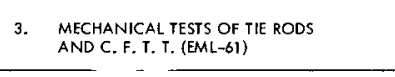 & 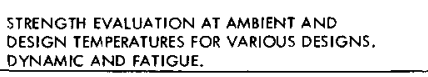 & & $-x-$ & $-\quad \mathrm{Fz}-$ \\
\hline & 4. BUNDLED CLUSTERS (EML-60, 67) & 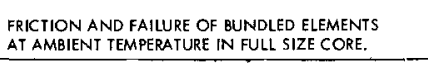 & & & $\underline{\mathrm{F}} 2 \ldots$ \\
\hline & $\begin{array}{l}\text { 5. FUEE EEEMENT SUPPORT BLOCK INTERFACE } \\
\text { COAING FRICION AND WEAR TEST } \\
\text { (EML-75) }\end{array}$ & $\begin{array}{l}\text { DETERMINE FRICTON FOACES AND COATING } \\
\text { DAMAGE. }\end{array}$ & $--x-\ldots$ & & \\
\hline \multirow[t]{5}{*}{ D. LATERAL SUPPORT SYSTEM TESTS } & $\begin{array}{l}\text { 1. LATERAL LUPPORT SPRING TESTS } \\
\text { (EML-B6) }\end{array}$ & $\begin{array}{l}\text { EVALUATE RELAXATION OF SPRINGS UNDER } \\
\text { REACTROR TEPBREATURE \& VBRATION } \\
\text { ENVIRONMENTS. }\end{array}$ & $-x-$ & & $-\mathrm{Cl}--$ \\
\hline & 2. SEAL SEGMENT TESTS (EML-86) & EVALUATION OF NEW SEAL SEGMENT DESIGNS. & & & $-\mathrm{c} 2-$ \\
\hline & 3. SEAL RETENTION TESSS (EML-86) & DEVELOP NEW SEAL RETENTION METHOOS. & & & $-\mathrm{c} 2 \ldots$ \\
\hline & 4. LATERAL SUPPORT PUUNGER TEST (EMLL-86) & DETRRMINE FLEXURAL STRENGTH. & & & $=-\mathrm{cs}=$ \\
\hline & 5. PARTIAL CORE DWNAMIC TESTS (EML-E6) & 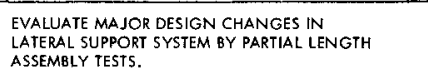 & $-3.34 .1-$ & & $-\mathrm{c} 2-$ \\
\hline \multirow[t]{4}{*}{ E. CORE PERIPHERY AND INTERSTITIALL TESTING } & 1. CORE PERPPHERY TEMPERATURE TESTS(EML-68) & 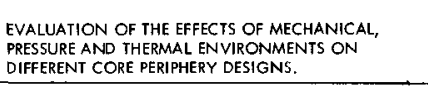 & & & $-F_{4}-$ \\
\hline & $\begin{array}{l}\text { 2. COMPONENT INTEREACE FRLCTION \& WEAR } \\
\text { TESTS (EML-75) }\end{array}$ & 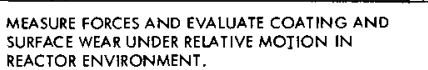 & $-x-$ & & $-\mathrm{C}_{4}-$ \\
\hline & $\begin{array}{l}\text { 3. ORE EFFECTIVE GAP IESTS } \\
\text { (EML-60) }\end{array}$ & $\begin{array}{l}\text { TO EEALATE INTERSTITIAL GAAS OF LARGE } \\
\text { CoRES }\end{array}$ & $=\times=$ & & 二F2- \\
\hline & $\begin{array}{l}\text { 4. CORE PERPHAREY ELEMENT SUPPORT } \\
\text { (EMLL-94) }\end{array}$ & $\begin{array}{l}\text { QULAFICATION OF DESIGN BY APPLIED } \\
\text { LAOS TO PARTIAL ELEMENT/FILER STRIP } \\
\text { DESIGNS }\end{array}$ & $5.1-$ & & \\
\hline \multirow[t]{7}{*}{ F. DOME END TESTING } & 1. PLeNUM FEED MANIFOLD (EML-74) & $\begin{array}{l}\text { QUALIFICATION OF DESIENS BY MECHANICAL } \\
\text { INTEGRIT, VIRATION AND LAK LESTS. }\end{array}$ & & & $--E_{5}-$ \\
\hline & $\begin{array}{ll}2 . & \begin{array}{c}\text { SHIED SLUG DEVELOPMENT } \\
(\text { (EML-84) }\end{array} \\
\end{array}$ & $\begin{array}{l}\text { EVALUATE THERMLL SHOCK DATA AND } \\
\text { VACUUM TESTS OF SWUG MAERRAL }\end{array}$ & & & $-\mathrm{DH}-$ \\
\hline & $\begin{array}{ll}\text { 3. } & \begin{array}{l}\text { SHELD CLUSTER DEVELOPMENT } \\
\text { (EML-84) }\end{array} \\
\end{array}$ & 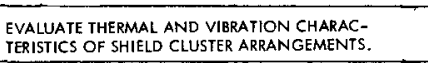 & & & $-0 ?-$ \\
\hline & 4. SHHELD ASSEMBLY (EML-74) & $\begin{array}{l}\text { OEMONSTRRAE CAPABLITY OF SHIEL ASSEMULY } \\
\text { BY VIBRATION IESSS. }\end{array}$ & & & $=03-$ \\
\hline & 5. SUPPQY PLENUM (ENL-74) & $\begin{array}{l}\text { DEVELOP SUPPLY PLENUM CAPABLE OF } \\
\text { REACTOR OPERAIION. }\end{array}$ & & & {$[\mathrm{E3}-$} \\
\hline & 6. SUPPORT PLATE (EML-74) & $\begin{array}{l}\text { OUALIFICATION OF SUPPORT STRRCTURE BY } \\
\text { MECHANCAL AND THERMAL TESTS. }\end{array}$ & & & $-E 6-$ \\
\hline & $\begin{array}{l}\text { 7. AFI SUPPOORI SYSTEM STATIC AND } \\
\text { DWNAMK PROOF TESTS (EML-74) }\end{array}$ & $\begin{array}{l}\text { OUALLIIIATION OF ADVANCEE DESIGN CORE } \\
\text { AAT SUPPORI TTRUCTURES. }\end{array}$ & & & $-{ }_{-A G-}$ \\
\hline \multirow[t]{2}{*}{ G. CORE ASSEMBLY TESTING } & $\begin{array}{l}\text { 1. FUL ASEMBBYY DYNAMIC TESTS } \\
\text { (EMLL-101) }\end{array}$ & 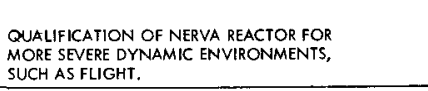 & & & $-\mathrm{C} 5-$ \\
\hline & 2. POST-OPERATIVETEST & $\begin{array}{l}\text { COMPARSON OF COMPONENT CHAAACTERISTICS } \\
\text { BEFFORE AND AFTER REACTTRO OPEAATION. }\end{array}$ & $-x-$ & & \\
\hline \multirow[t]{3}{*}{ H. FACLLTTY, LAUNCH \& FLIGHT TESTING } & 1. RESONANT SURVEY (EML-55) & $\begin{array}{l}\text { OETERMIINE ENGINE TEST STAND AND } \\
\text { REACTOR RESONANCES. }\end{array}$ & $\omega x-$ & & \\
\hline & 2. COMPONENT ACOUSTIC TESTS (EMLL-95) & $\begin{array}{l}\text { DETERMINE EFFECT OF HIGH INTENSITY ACOUSTIC } \\
\text { PRESSURES ON SELECTED COMPONENTS. }\end{array}$ & & $-x-$ & \\
\hline & 3. VACUUM TEST & 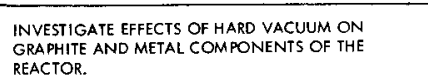 & & & $\longrightarrow$ \\
\hline
\end{tabular}




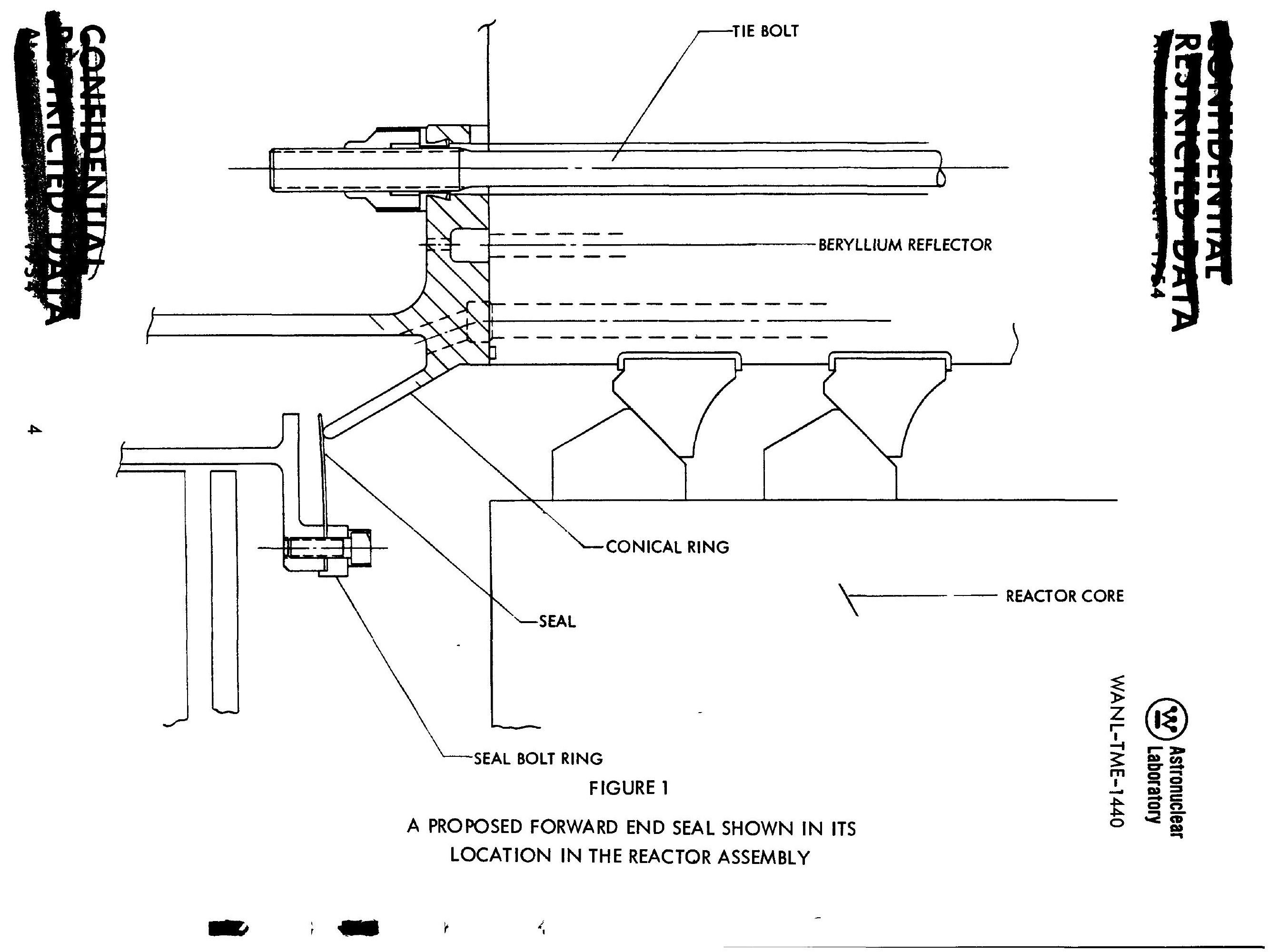


in the anticipated engine environments. The development tests will evaluate decoupling mechanisms, drive band fatigue strength and the effects of vibration and vacuum environments on the function of the components. The system tests will evaluate the behavior of the complete system and the effects of the engine vibration environments. A plan view of the proposed ganged drum is shown in Figure 2, while a cross-section is shown in Figure 3.

5. Control Drum (or Sleeve) Tests

Tests are to be performed under simulated startup flow conditions to investigate and minimize the thermal bow that will occur during reactor testing. In these tests, the various startup flow ramp and initial drum temperature conditions expected during reactor testing will be reproduced.

6. Thermal Contact Resistance

At present the thermal analysis of the core periphery and the reflector requires that assumptions be made regarding the thermal resistance at the interfaces between the various components. Additional test data is required to improve the accuracy of the analysis in this area. The data should provide the thermal conductivity of the interfaces between the various components (e.g, graphite on graphite, pyrofoil on beryllium) as a function of temperature, differential pressure, pressure, nom inal forces, surface hardness and finish, and the type of atmosphere.

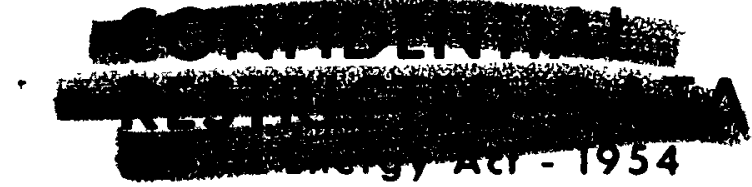




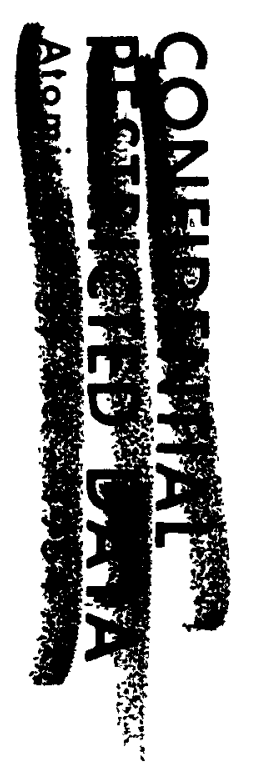

FIGURE 2

A PLAN VIEW SHOWING THE DRIVE BAND ARRANGEMENT OF THE PROPOSED GANGED DRUM ASSEMBLY

$a$

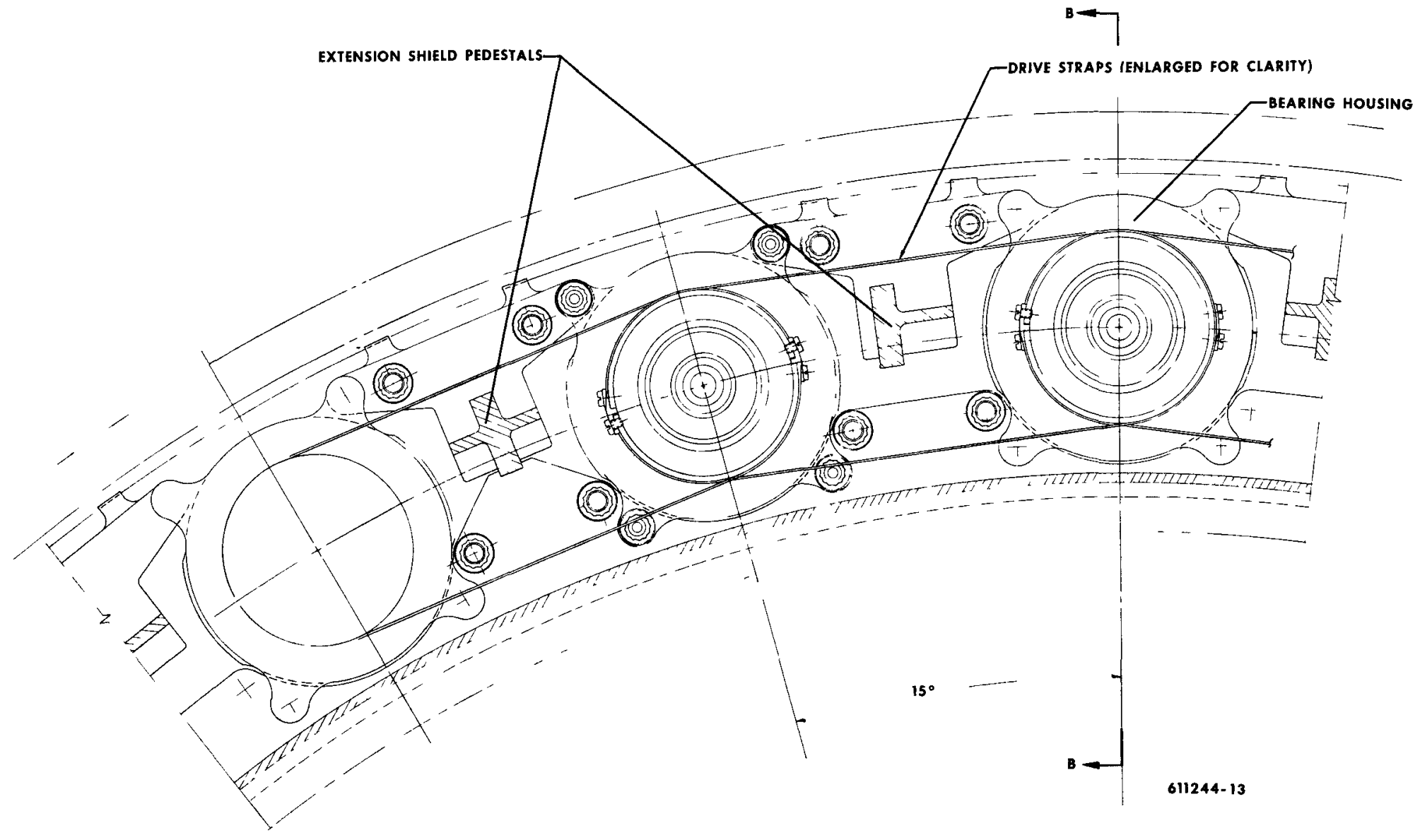

SECTION A-A
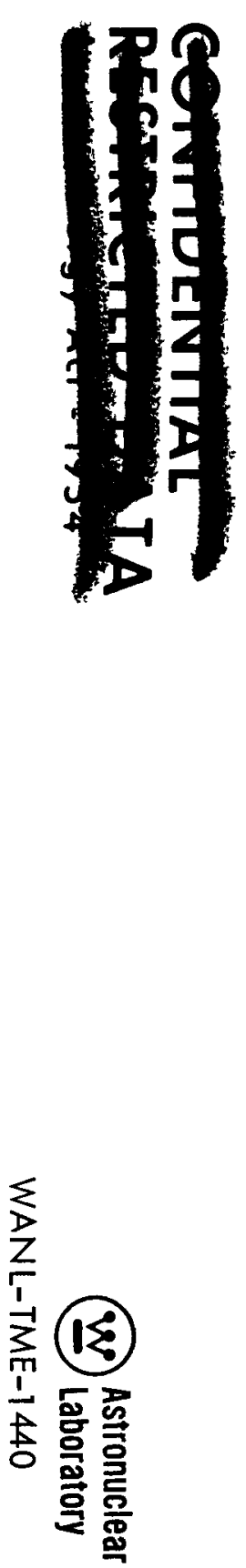


\section{FIGURE 3}

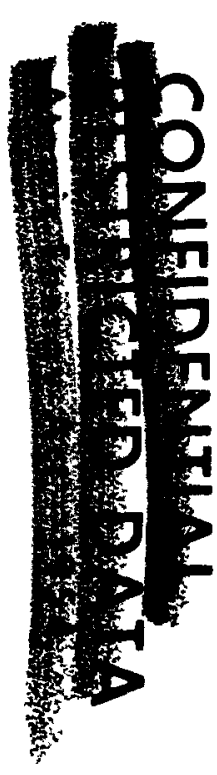

SECTION THROUGH THE GANGED DRUM ASSEMBLY (SEE FIGURE 2)

SHOWING DETAILS OF THE SYSTEM

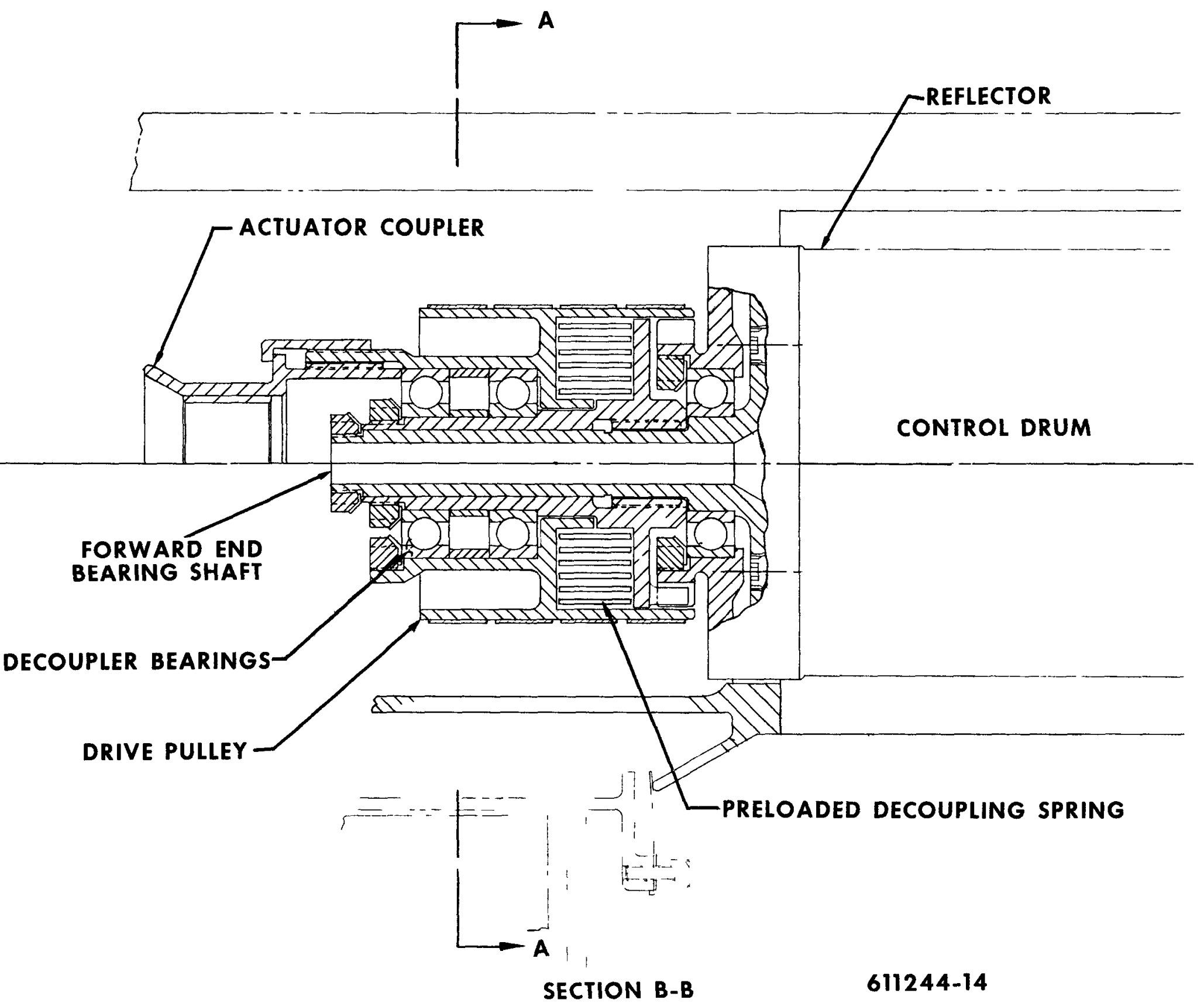




\section{B. FUEL ELEMENT TESTING}

Page 1 of 3

With the proposed changes in operating element temperature void fraction (or pressure drop), and dimensional changes of the NR-1 elements compared to the NRX-A fuel elements, it will be necessary to conduct development and proof tests similar to those conducted on NERVA I elements. Investigations of corroded elements as well as virgin elements are desirous to realize the element lifetime for the longer reactor operat ing times of NR-1. The effects of design changes and the effects of changes in reactor operating conditions must be determined relative to element compressive, tensile, and bending properties. In addition, the porosity and creep properties, coating adherence and aft end integrity of developmental and prototype NR-1 elements must be investigated. The detrimental effects of thermal cycling of element bore coatings and of thermocouple installations will be determined.

1. Fuel Element Strength Tests

The NR-1 fuel element testing is intended to determine the mechanical properties of new fuel element designs before use in the reactor. The test program will provide physical property data on new element designs for use in analysis. Test specimens will include both new and corroded elements for comparison of results. The purpose of these tests is to provide data on development fuel element specimens.

a. Compression Test - Fuel element specimens of two inch lengths will be tested over a range from room temperature to $5200^{\circ} \mathrm{R}$. The test will provide data on ultimate load and strain, as obtained by optical methods, as functions of temperature.

b. Tension Tests - Development specimens will be tested under tensile loads over a range of temperatures from room to $5200^{\circ} \mathrm{R}$. The test will include strain measurements by optical methods as well as ultimate load and mode of failure data.

c. Bending Tests at Temperature - The lateral creep of development elements will be determined as a function of time for temperatures up to $5000^{\circ} \mathrm{R}$. Testing will also include bending tests of element end designs at temperature.

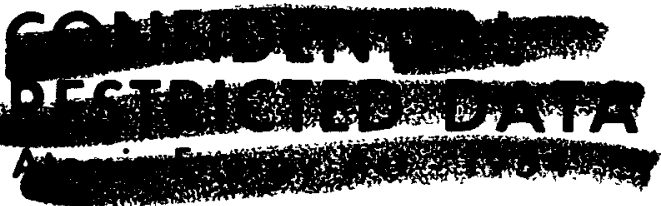




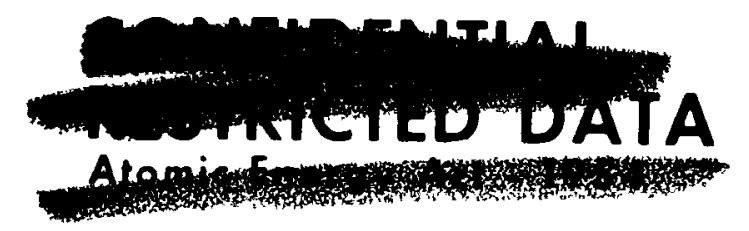

(W. Astronuclear

WANL-TME- 1440

Section B

Page 2 of 3

d. Element Orifices - This test will determine the strength of orifice braze joints and the sealing ability of this joint.

e. Porosity Tests - The porosity of fuel elements and selected lateral support graph ite materials are to be determined as a function of temperature. Porosity will be determined for coated and uncoated elements.

f. Vibration and Fatigue Tests - These tests will determine the basic natural frequency for new elements and will determine the low cycle fatigue strength of the design.

\section{Fuel Element Coating Tests}

The integrity of coatings used on the NR-1 fuel elements is to be determined by testing at simulated reactor temperatures. A typical testing setup is shown in Figure 4

a. Coating Test - In this test the elements are to be assembled into a short cluster (five inch long elements and a support block) and tested under reactor loads and temperatures. The test will provide data on the integrity of coating at the hot end, the tendency for corrosion to take place in the gaps formed by the undercuts and the integrity of the unfueled end joint. In addition, the short cluster can be thermally cycled between any desired temperatures by removing and re-injecting the short cluster into the furnace hot zone. This test will aid in evaluating the effect of thermally flexing the niobium carbide coating on the element aft end and in the flow holes. Short cluster tests are also to be used to study various element aft end designs (such as carbide tips) in a corrosive hot hydrogen environment and to evaluate the coating adherence integrity at the various transition joints.

b. Welding Test - In this test the interface area of the element aft ends and the support block are to be investigated under conditions of various temperatures, times, interface pressures (cluster, axial loads) and gaseous surroundings (inert, hot stagnant hydrogen, flowing hot hydrogen, etc). The integrity of the coating to withstand or resist welding at the interface will be determined for various reactor element aft end designs. 


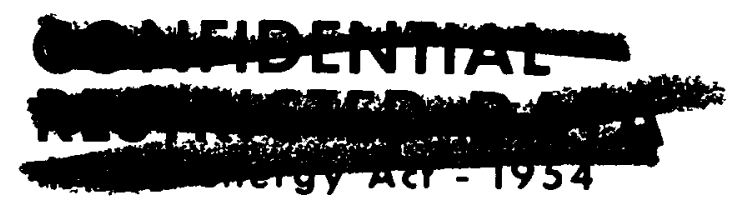

(20) Astronuclear WANL-TME-1440

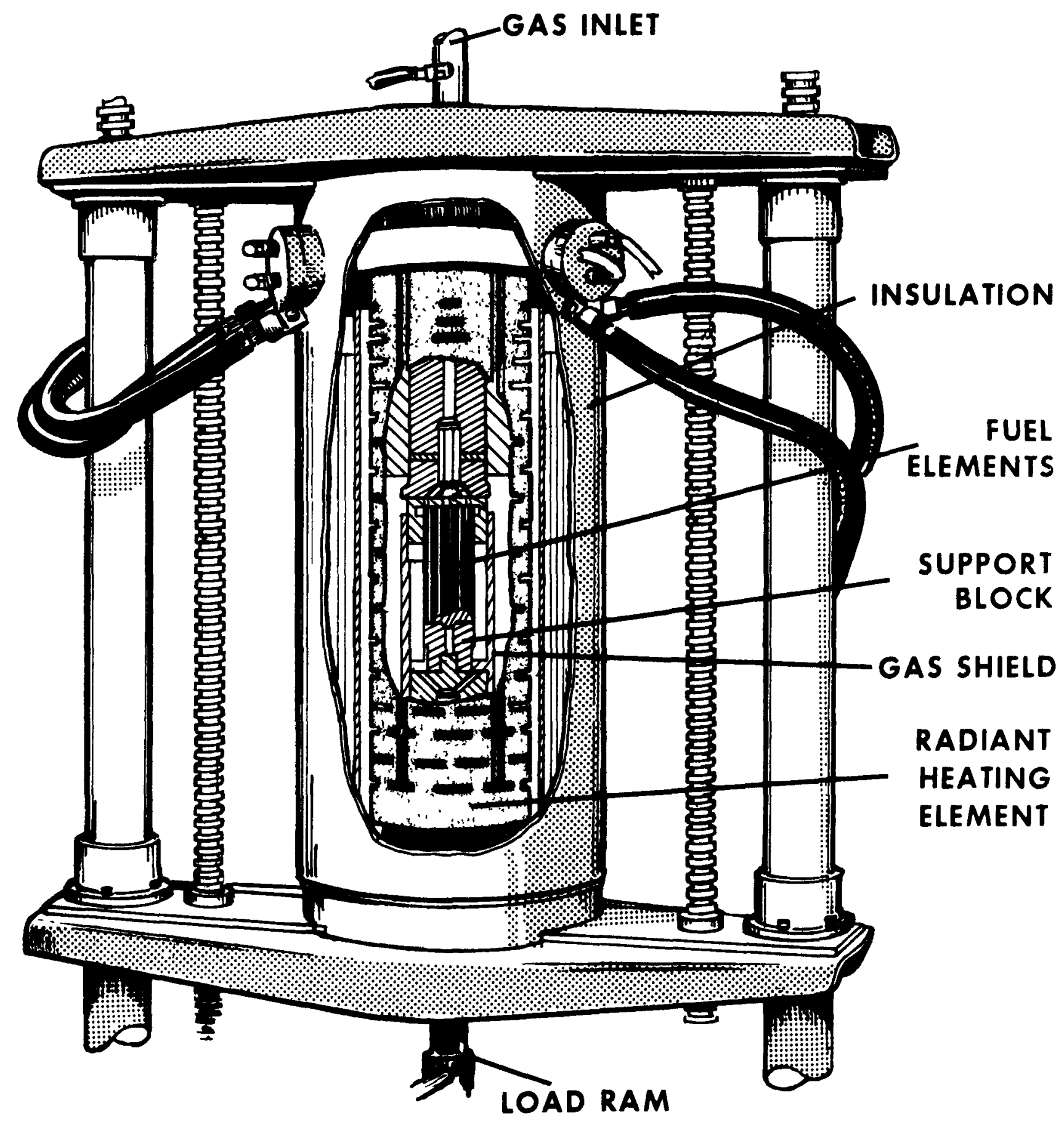

FIGURE 4

A GENERAL ARRANGEMENT SHOWING THE HIGH TEM PERATURE TESTING OF FUEL CLUSTER ASSEMBLIES AND ASSOCIATED HARDWARE 


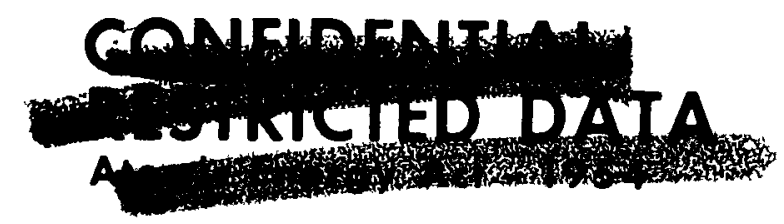
(20) Astronuclear Laboratory

WANL-TME- 1440

Section B

Page 3 of 3

3. Fuel Element Instrumented Installation Testing

This test is intended to evaluate the effect of thermocouple and transducer installations on the fuel element. The installation, as present considered, replaces a fueled element with an unfueled element having the instrumented installed. The test details will be affected by thermal and stress analysis. The tests presently visualized are element strength and thermal gradients.

a. Fuel Element Strength - The affect of the installation on compression and/or tension strength will be determined at temperature.

b. Thermal Gradient Testing - The affect of thermal gradients will be determined for the installation. 
(W) Astronuclear Laboratory

\section{AXIAL SUPPORT SYSTEM TESTS}

WANL-TME-1440

Section $C$

Page 1 of 4

In line with results from actual reactor results and developmental testing, problems associated with the axial support system are to be investigated in depth.

Alternate designs of support block systems which eliminate the most highly stressed areas as well as redesigns of the current block configuration must be tested against the more severe criteria of the $A 6$ and $N R-1$ reactors. To approach the problem from another viewpoint tests are required to evaluate the means of supporting a cluster from the cold end instead of the hot end and to evaluate problems associated with interface relationships of contiguous element coated surfaces. Likewise the effect of porosity on element structural integrity must be investigated. The mechanical strength of counterflow tie rods and tie tubes must be determined to support development of components necessary for increased requirements of higher powered reactors. Buckling tendency of thin walls, threaded strength and leakage must be shown to be with in adequate limits for the proposed usage. In line with the possibility of tie rod failure it is necessary to determine the restraint on cluster movement by bund ing pressures at various stations of the reactor. Experimental work along these lines on a seven assembly cluster will be extended to a larger area to ascertain the effects of bridging where a greater mass is involved. 1. Support Block Strength

The purpose of the NR-1 support block tests is to develop blocks that are capable of meeting all of the criteria established for operation of this reactor. The tests presently intended for use in block development are based on the best available information to date.

These tests are designed to provide development data on candidate block designs and to provide answers to specific problem areas such as welding and thermal gradients. a. Thermal Gradient Tests - The support block assembly will be placed in a resistance furnace and will be held at a design compressive load of approximately $600 \mathrm{lb}$. The assembly will then be heated to reactor full power operat ing temperatures. Maximum attainable thermal gradients will be obtained by introducing cold fluid through the center tie rod hole. An inert atmosphere of helium will be introduced 
into the furnace chamber. The furnaces are equipped with a test fixture for application of mechanical loads.

Additional gradients will be produced by directing a stream of cold gas on the side of a support block at temperature in the furnace to simulate the effect of cold gas impingement in the reactor. To get a longer path for heat flow an irregular two hole block will be cooled through one of its center holes while exposed to radiant heat addition at reactor temperatures.

b. Welding Tendencies of Coating - Coated support blocks and corrosion cups will be loaded at temperature in a hydrogen atmosphere to investigate the tendency to weld under these conditions. Various materials and additives will be interposed between the components to determine their effect in preventing the welding phenomenon.

c. Vacuum Tests - Coated support blocks, and associated hardware will be tested in a vacuum up to $5 \times 10^{-9}$ torr to investigate coating adherence and welding. The test will determine the weight loss, affect on coating adherence, and presence of vacuum welding for specimens as a function of time.

2. Cluster Development Testing

The purpose of the NR-1 blockless cluster testing is to develop a cluster design that will solve the support block cracking, coating, and welding problems and will meet all of the criteria established for the reactor. The test program is intended to evaluate various designs and develop promising candidates for use in the reactor.

The tests are designed to provide detailed development data on candidate cluster configurations.

a. Crack Initiation Tests - The crack initiation load, mode of failure, and ultimate load will be determined for both short and full length cluster assemblies under reactor bundling pressures. Testing will be done at room temperature and at elevated temperatures. 


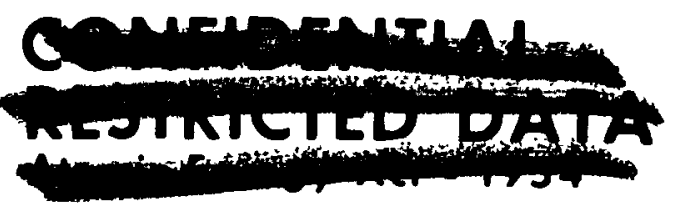

Q Astronuclear

WANL-TME-1440

Section C

Page 3 of 4

b. Bundling Tests - New cluster designs will be tested in a seven cluster or full core assembly under bundling loads to determine the strain distribution along the length of elements. The test will be capable of simulating tie rod or other failures to determine the redistribution of loads on adjacent components.

c. Load Cycling - The effect of repeated loading on critical components will be determined for both short and full length clusters at room temperature and at high temperature.

d. Stress Rupture - The resistance of cluster components to stress rupture effects will be done in a transverse test fixture under fixed loads at temperatures to $4750^{\circ} \mathrm{R}$.

e. Vacuum Tests - Blockless cluster support components, cements, brazed joints or other fasteners will be tested in a vacuum to $5 \times 10^{-9}$ torr. These tests will be followed by strength tests to determine any loss of physical or structural properties after sustained periods in a hard vacuum.

3. Mechanical Tests of Tie Rods and Tie Tubes

a. Counterflow Tie Tube Development Tests - Testing is required to develop the counterflow tie tube assemblies now being proposed to the point where they can be incorporated in the reactor with a high degree of confidence that failure will not occur during reactor operation. It is anticipated that the tests in this program would be performed to optimize head and dome end tie tube configurations. A proposed configuration is shown in Figure 5.

Structural testing is required for both the tie tube and counterflow tube. In addition to tensile tests, lateral flexibility and fatigue tests will be conducted on the forward end of the tie tube assembly. Tests to determine the resonances and damping characteristics of the tube assembly will be conducted to define the tube centering requirements.

1. Tensile tests - Tests will be performed to determine the structural durability of the nozzle end; the tensile properties and their uniformity, the failure mode, the effects of temperature on the strength of the tie 


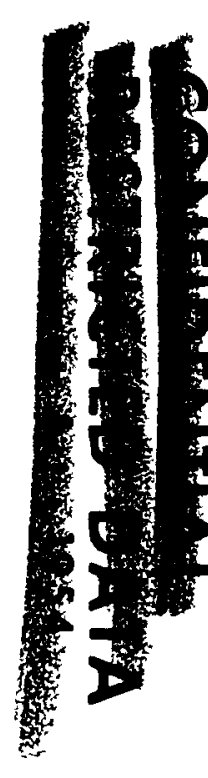

$\vec{u}$

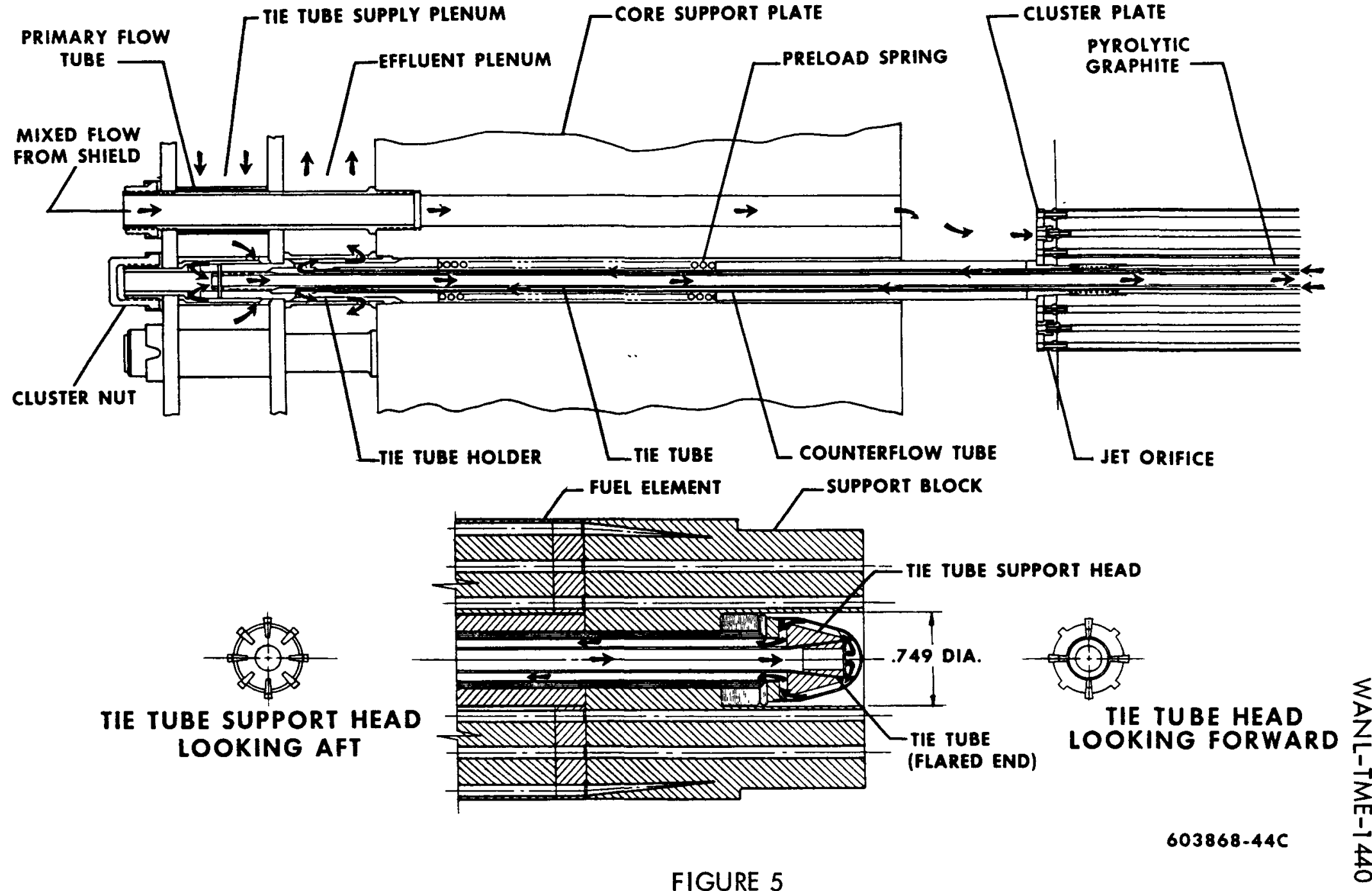

FIGURE 5

THE PROPOSED COUNTERFLOW TIE TUBE ASSEMBLY SHOWING

THE FLOW PATH AND END CONFIGURATIONS 
tie tube and mechanical joint structure.

2. Buckling Tests - Tests will be performed to determine the buckling characteristics of the outer (counterflow) tube.

3. Fatigue Tests - Tests will be performed to evaluate the durability of tie tubes under combined axial bending loading and to compare the performance with that of the standard tie rods.

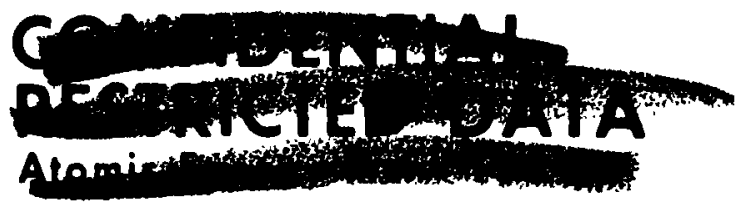




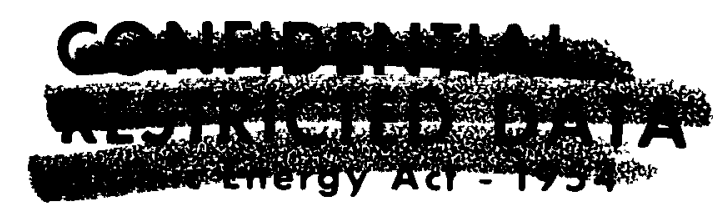 (2) Astronuclear
WANL-TME-1440
Section D
Page 1 of 2

\section{LATERAL SUPPORT SYSTEM TESTS}

Tests of the lateral support system components will be performed at operating conditions to develop the design and to insure that they will meet the design requirements. The components that will be tested include the support spring, seal segments, seal retention device and support plunger. Figure 6 shows an assembly of the components as proposed for NERVA reactors.

1. Lateral Support Spring Tests

Tests will be performed to investigate the cooling and relaxation of the lateral support spring. The spring is subjected to the heating and vibration conditions expected during reactor operation.

2. Lateral Support Seal Segment Tests

Tests will be performed to determine the mechanical properties of the proposed seal segment designs and to investigate their function under operating conditions. The flexural strength of the seal segments will be determined at temperatures bracketing all operating conditions, and the segments will be cycled to simulate the motions expected during reactor operation.

3. Lateral Support Seal Retention Tests

Tests will be performed to develop a method to locate and restrain the seals in position during reactor assembly. Ambient tests will be performed to determine whether the seal is held as desired during assembly, and tests at operating temperature and loading conditions will be performed to determine how the retaining device may affect the function of the seal during reactor operation.

4. Lateral Support Plunger Tests

Tests will be performed to determine the strength of the plunger to react loads normal to axis of the plunger. A plunger assembly will be mounted in a standard testing machine and loads will be applied to the end of the plunger pin oriented at ring angles to the plunger pin axis. Measurements of load and deflection will be made. 


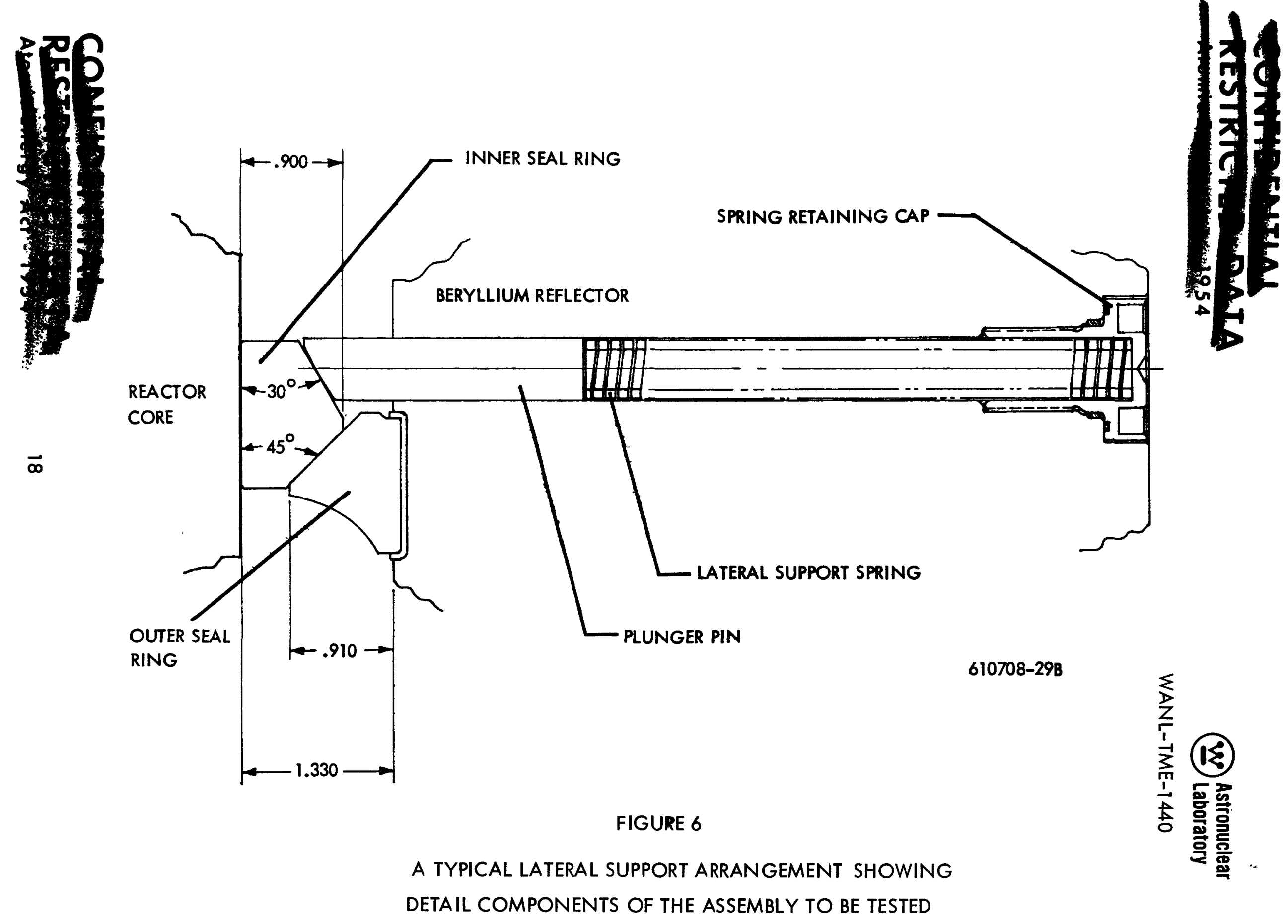




\section{Partial Core Tests}

The NR-1 lateral support system is significantly different from previous NRX reactors due to larger core diameter and a higher heating rate. Differences in the support system design under consideration include hollow seal segments, piston-type lateral support seal (between scarf joints), spring designs and seals around plunger pins. The friction characteristics, structural integrity, fastener effectiveness and component wear cannot be fully evaluated by analysis alone.

Several phases of testing are required to evaluate the lateral support system. Static tests would provide static friction characteristics; dynamic tests will determine the system's response to known inputs, and seal leakage tests would show the effectiveness of the seals. The possibility of loss of sealing due to permanent core shift caused by friction lockup of the lateral support system will be investigated. All tests would yield information pertaining to structural integrity and component wear.

Testing will be performed using a full diameter, partial length core assembly. Values obtained from the test model can be extrapolated for the full length core. A basic test model would be planned to permit evaluation of several different combinations of seals, plungers and springs.

The partial core will also be used to evaluate the installation of reactor instrumentation such as the core displacement transducer. 


\section{E. CORE PERIPHERY TESTING}

Page 1 of 2

The reactor periphery presents an unusual design problem because of the combination of thermal gradients, mechanical loads, and pressure differentials. These factors contribute to the radial inflow and support problems of peripheral components. Associated with these is the affect of friction and wear at the interfaces of seal segments, filler strips, insulating tiles, fuel elements, partial elements, etc. The core periphery testing will provide development data on peripheral components to permit continued improvements in these designs.

1. Core Periphery Temperature Tests

This test is designed to permit rapid evaluation of the various peripheral concepts under consideration for the NR-I reactor.

A mockup of a small section of the core periphery is planned to provide data under simulated conditions of mechanical load, pressure and temperature. The test is capable of independent control of bundling loads, axial element loads, temperature, differential pressure, and pressure. In addition, room temperature properties of filler strips, peripheral elements, and filler strip support techniques will be determined.

Figure 7 shows the test setup of a typical core configuration.

a. Room Temperature Properties - The structural integrity of filler strips and/or keyed elements will be determined under simulated lateral restraint at room temperature.

b. Performance Characteristics - This test will determine the effects of temperature, pressure, bundling load, axial load, and differential pressure on mechanical and thermal distortion of peripheral components. The pressure distributions across the periphery and the effects of mechanical and thermal variables will be determined for each configuration under test.

c. Filler Strip Support Test - This test will be at ambient temperature and will determine the strength of the final configuration in a simulated core assembly. The test will apply independent axial loads to each filler strip to determine the ultimate load and mode of failure of the filler strip support design.

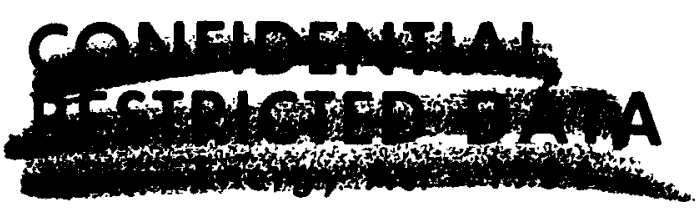




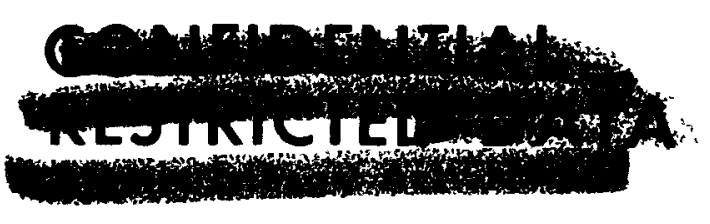

(W. Astronuclear

WANL-TME-1 440

FIGURE T

A GENERAL ARRANGEMENT FOR TESTING CORE PERIPHERY DESIGNS
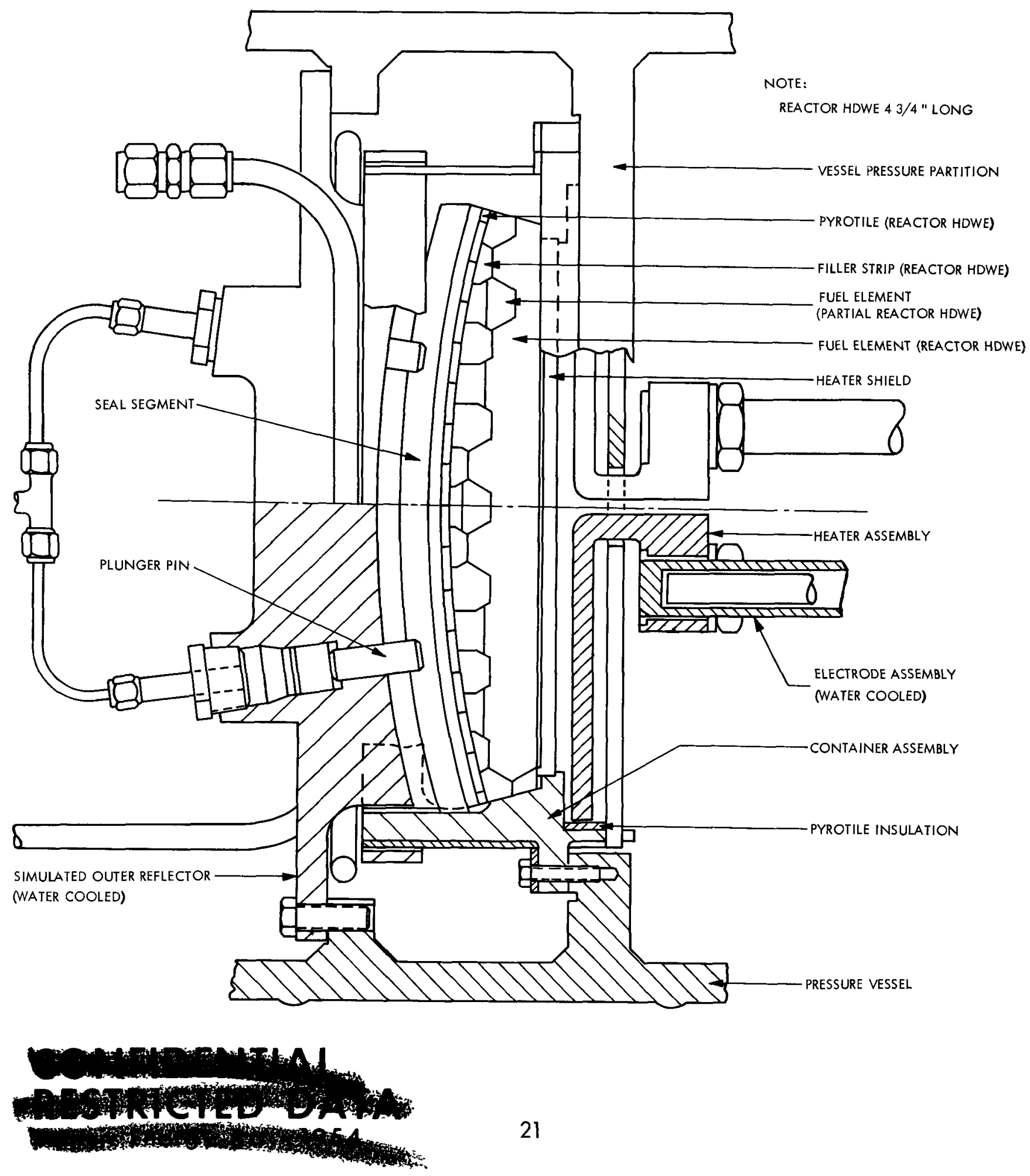
2. Component Interface Friction and Wear

Tests will be performed to determine friction forces and damage of all the coated and uncoated core component interface surfaces that can result from relative motions of core components during reactor assembly and reactor operation.

3. Core Gap Test Program

An evaluation of interstitial gap dimensions for larger cores is required. This information can be used in conjunction with flow data on narrow channels between graphite components to predict more accurately interstitial flow and corrosion.

It is planned to conduct interelement gap experiments to provide internal core pressure data to aid in understanding the effects to fuel element corrosion and out-ofsize element dimensions. Stack-up of out-of-tolerance elements of such a wide core area as is present in NR-1 may create gap "rivers" which can have a marked effect on flow rates and distributions.

The interelement radial flow impedance of the core under various bundling pressures would be mapped. The effects of element surface conditions in the peripheral area will also be evaluated.

4. Core Periphery Element Support

Removal of lobes beneath the partial elements in the J-3, J-5 and J-9 support blocks necessitates partial element support changes which require qualification. Axially applied static load testing of the forward supported partial element/filler strip combination is required. The test setup will consist of a full core diameter of bundled 10-inch length fuel elements. Axial loading will be applied to filler strips by small individual hydraulic cylinders. Test setups will be similar to those used to evaluate the transition region between the buffer and conventional filler strips on the NRX-A 5. 


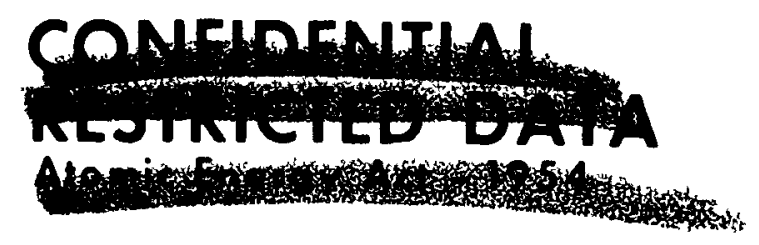

Astronuclear

Laboratory

WAN L-TME-1440

Section $F$

Page 1 of 2

\section{F. DOME END TESTING}

Tests of the dome end components will be performed to develop the design of these components and insure that they will meet the design requirements. The components that will be tested will include the shield inserts, a shield element, shield assembly, counterflow supply plenum, counterflow support plate and aft support structure.

1. Counterflow Plenum Feed Manifold

At present, the routing of the feed lines and the support brackets to the counterflow tie tube plenum has not been finalized. Tests are required to evaluate the optimum configuration which will successfully withstand static and vibratory londings.

The plenum feed configuration will be vibrated to determine the natural frequencies and damping characteristics of the system in both the axial and lateral directions. The system will be pressurized to 1000 psi and held at cryogen ic temperatures during the vibration tests. From this evaluation, recommendations will be made as to the ideal placement of the support hardware in order to minimize any deleterious effects which may exist in the system.

\section{Shield Slug Development}

Thermal tests will be performed to assist in selecting a shield material capable of withstanding thermal transient conditions established for reactor operation without cracking. Shield slug composites will be tested by rapidly chilling the surface of the slug with a high velocity cryogenic gas flow. Thermal gradients will be measured and the gradient required to crack the slug will be determined.

\section{Shield Cluster Testing}

Shield clusters assembled in a representative section of the shield will be subjected to the engine vibration environments at cryogenic temperatures with an electrodynamic shaker. Figure 8 shows a proposed cluster arrangement and Figure 9 is a cross-section through the shield cluster.

4. Shield Assembly Testing

Tests will be performed to demonstrate the ability of the shield assembly to with-

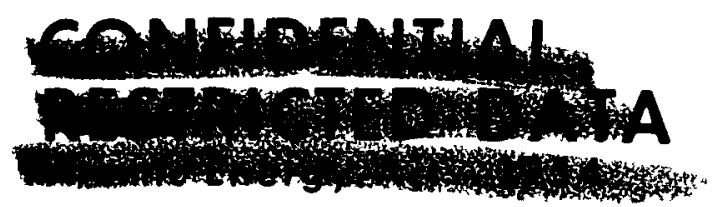



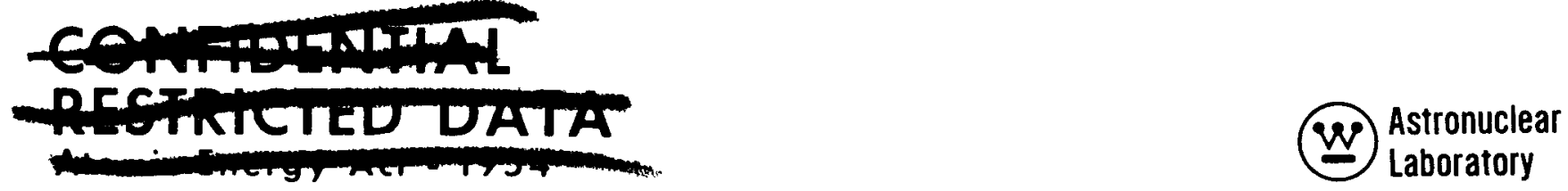

WANL-TME-1440

FIGURE 8

THE PLAN VIEW OF A PROPOSED SHIELD CLUSTER ASSEMBLY IN WHICH

THE SHIELD IS LOCATED BELOW THE CORE SUPPORT PLATE

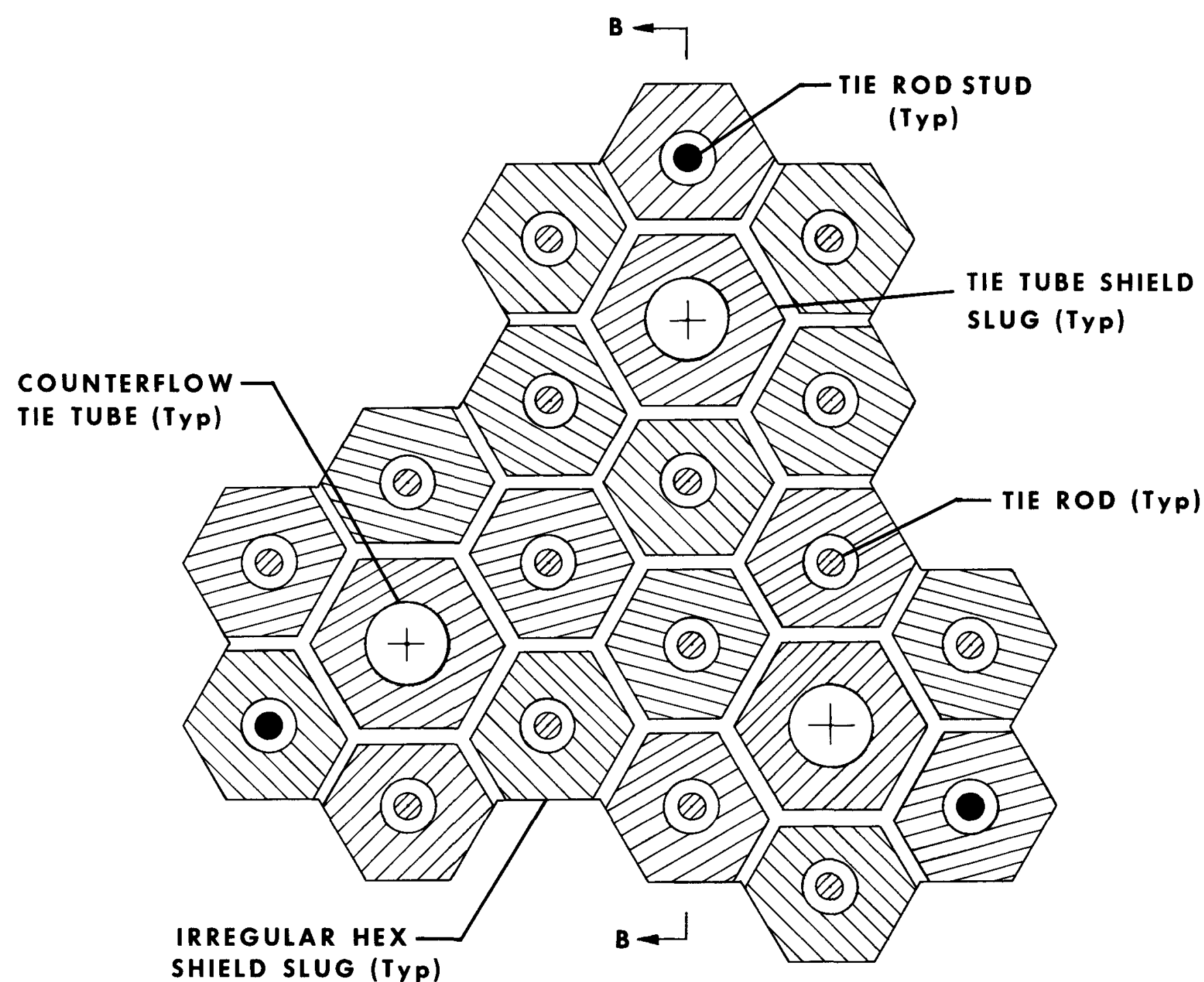

$611244-6 C$ 
FIGURE 9

A TYPICAL CROSS-SECTION VIEW OF THE SHIELD ASSEMBLY SHOWING DETAIL COMPONENTS

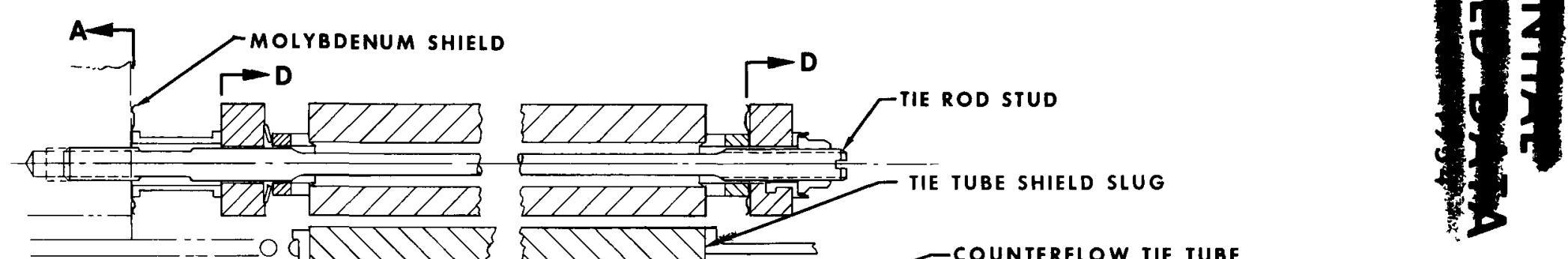

u

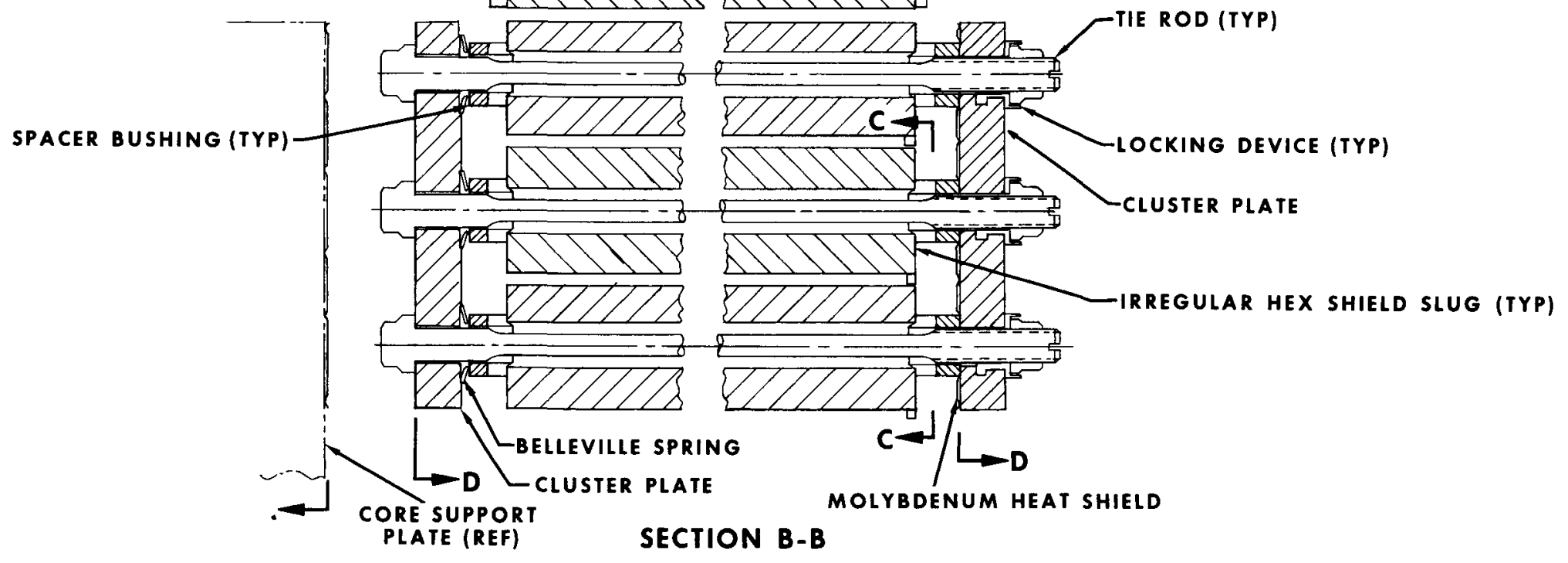

$611244-7$

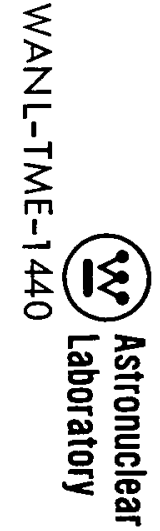


stand the loads and vibrations anticipated during the operation of the reactor. The shield assembly for the cold flow development test specimen will be mounted in a test rig that will provide stiffness and support simulating reactor conditions and will be simultaneously loaded mechanically and vibrated at cryogenic temperature. Also, effects of frequency sweeps through levels anticipated at reactor levels will be determined by measuring strains and displacements.

5. Counterflow Supply Plenum Tests

Tests will be performed to develop a counterflow supply plenum capable of withstanding pressure differentials and deformations resulting from thermal gradients. Small sections of plenum designs will be tested at established pressure differentials to determine leak rates while subjected to thermal gradients anticipated during reactor operation.

6. Counterflow Support Plate with Plenum

Tests will be conducted to demonstrate the capability of the counterflow support plate with plenum to withstand vibration effects and axial loads that are anticipated during the operation of the reactor. Also tests will be made to determine the capability of the plenum to withstand pressure loading and pressure differentials without failure or excessive leakage.

7. Aft Structural Support System

Tests will be performed to demonstrate the capability of the aft structural system (Figure 10) to support the core and reflector when subjected to a maximum of $250 \mathrm{psi}$ core pressure drop load and six $\mathrm{g}$ inertia load. The tests will be performed at cryogenic temperature so anticipated differential radial displacements between components of the support system fabricated of material with different coefficients of expansion will be obtained. 
FIGURE 10

A CROSS SECTION OF THE AFT END SUPPORT STRUCTURE

SHOWING THE DETAIL COMPONENTS

SECTION A-A

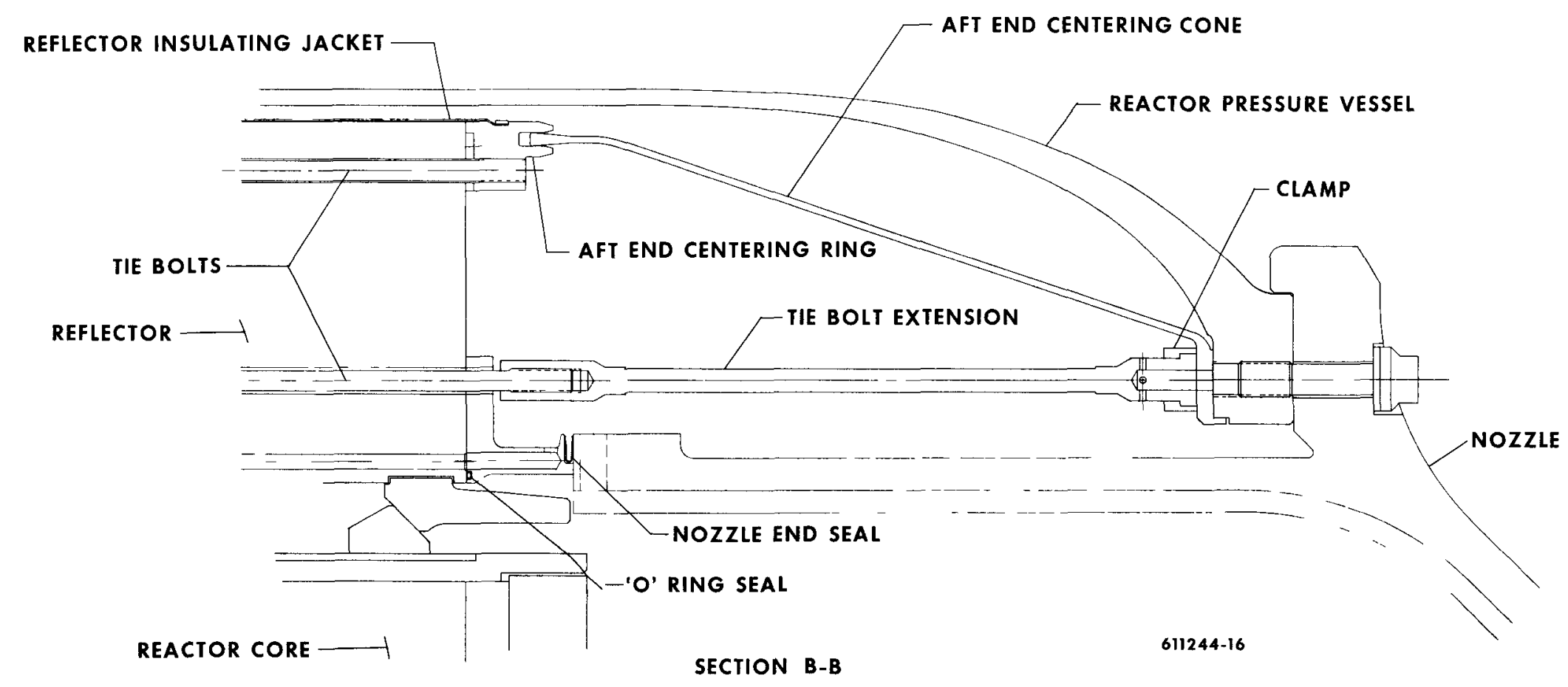

SECTION B-B 


\section{G. CORE ASSEMBLY TESTING}

1. Full Assembly Dynamic Tests

A systematic investigation of the NR-1 design requires the utilization of elements and procedures developed for the NRX-A reactor. Basic design information will be readily available for analytical studies. The development will indicate the response of the major components to external forces. From these and other proof tests in the laboratory, the knowledge and confidence in the final design will be increased.

In conjunction with Reactor Engineering, an analytical model of the major components will be generated to determine their behavior when subjected to sinusoidal vibratory inputs. Adequate techniques for simulating the vibration environment will be developed. This analysis will be used to aid in the design of test fixtures and definition of test procedures.

Sinusoidal vibration tests will be conducted on a full-scale nonfueled NR-1 size reactor. The first group of sinusoidal tests will verify the results obtained from the analytical model. In addition, the tests will:

a. Determine the ability of the reactor to withstand externally induced vibrations.

b. Determine relative motions between major components.

c. Confirm mechanical design factors.

d. Determine core isolation.

e. Determine the occurrence of impacting.

f. Determine any resonant conditions.

g. Determine the resistance of the components to fatigue failures.

h. Determine any non-linear affects.

i. Uncover areas in the reactor that should be analyzed more closely to investigate in a separate component test.

Sweep and dwell tests will be performed at varying levels during the above mentioned development tests. After these tests are completed, the reactor will be disassembled for a detailed inspection of the parts. At this time the reactor will be 


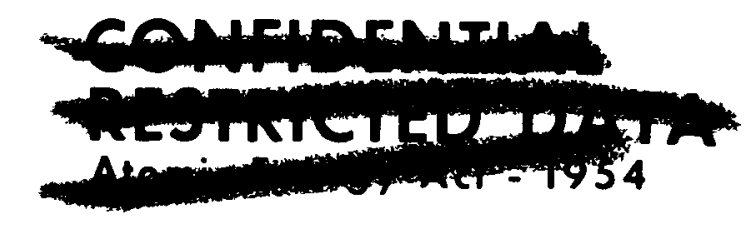

(W. Astronuclear

WANL-TME-1440

Section $G$

Page 2 of 2

upgraded to reflect any design changes that had occurred since the initial build.

The refurnished core will be tested at excessive levels of random vibration and shock which will simulate the environment of the spacecraft from the time of liftoff through the entire period of the flight mission. Levels for the sinusoidal and random vibrations will be those developed previously.

2. Post-Operative Tests

Compression tests will be performed on support blocks removed from the reactor to determine the ultimate strength as compared with previous tests on similar unirradiated blocks.

Sections will be taken from irradiated fuel element and flexed as short cantilever beams until failure. Various heat zones and locations in the reactor will be sampled and the flexure stress will be varied. Results will be compared with other reactors and non-irradiated elements.

Compression tests will be performed on corrosion cups and fittings to determine ultimate strength after being exposed to reactor environments.

Visual inspection of the beryllium reflector material are to be made. If required additional tests will be made to determine the effects of the reactor testing on the material. 


\section{H. FACILITY, LAUNCH AND FLIGHT TESTING Page 1 of 2}

1. Resonance Survey of Engine Test Stand 1

This test will provide a vibration response survey of the engine test stand structure and analysis of the structural response. This test is required to establish a basis for understanding the vibration responses seen in the engine test data and for evaluating any engine-structure vibration problems which may occur. The structure of ETS-1 differs significantly in flexibility from the test cars used for previous reactors tests.

2. Component Acoustic Test

Acoustic tests will be performed in an attempt to determine the effect of high intensity sound fields on the integrity of NERVA Core Components. As the integrity of any one component under actual NERVA operations will depend on the simultaneous action of several environments (i.e. shock, temperature, corrosion, acoustics, etc.), it is desired to investigate both the singular effects of acoustics and the combined effects of acoustics and these other environments.

a. Acoustic

Each test specimen will be subjected to the broad spectrum random noise field specified in MIL-STD-810A, Method 515 at a maximum overall sound pressure level of $155 \mathrm{db}$. The time of testing, however, will be varied to allow inspection of component damage.

b. Porosity

Porosity tests and weight measurements will be taken in an attempt to evaluate the combined effect of acoustical and corrosive damage. Polyvinyl chloride imprints of the channels of corroded element segments and the support blocks will help evaluate the effects of acoustics on the adherence of bore coatings and crack growth.

3. Vacuum Testing

Vacuum testing will be done with two main variables under control. These two variables are vacuum level and time. 
a. Reactor graph ite components will be tested in vacuum to determine weight losses as a function of time and vacuum level.

b. Reactor components will be tested to determine the extent of welding of various material combinations as a function of vacuum level and time.

c. Reactor components will be tested to determine the effect of difference in outgassing between the coating and parent graphite. Coating adherence tests will be performed to satisfy this objective.

d. Mechanical metal components requiring linear or rotary motion will be tested to determine the effect on performance as a function of vacuum level and time.

e. Friction data will be compiled on various reactor components subjected to relative motion as a function of vacuum level and time.

f. Sequential tests will be used to determine the effect of time in vacuum preceded and followed by other environmental tests that reactor components would see in flight. These were:

1. Vacuum testing followed by high temperature and pressure testing.

2. High temperature tests followed by vacuum tests.

3. Vacuum tests followed by high temperature and pressure tests followed by vacuum, etc. 


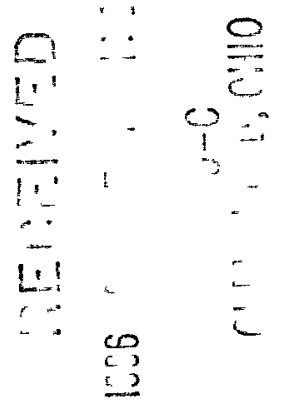

